\title{
"THE ONLY THING THEY HAVE TO BARGAIN WITH IS THEIR OWN SELF": masculinity and protesting immigration detention
}

\section{Transforming Cultures eJ ournal, \\ Vol. 2 No 1, November 2007 http:// epress.lib.uts.edu.au/ journals/TfC}

\section{Julie Browning}

\begin{abstract}
This paper explores questions around masculinity and immigration detention. It suggests that masculinity constitutes a dimension present in both the rationale for incarcerating unauthorised asylum seekers and in practices of resistance against their incarceration.

In modern Australia, the enclosed spaces of immigration detention are sites of bitter struggle. Brutality permeates the detention space and all detainees are vulnerable to its permutations, but men are the principal targets of the detention regime and are typically the primary instigators of mass demonstrations.

Group protests are a response to the constraining system of incarceration and seek particular resolution. In this masculine space a form of male resistance has publicised the devastation of detention.
\end{abstract}

[Keywords: masculinity, immigration detention, Australia, refugees]

\section{Introduction}

A history of protest exists within the places of non-criminal and indefinite detention ${ }^{1}$. This genealogy is perhaps predictable given that immigration detention is a space of inherent ambivalences: it is a hostile place, but at the same time one tied to offering some form of shelter to asylum seekers who may be identified as refugees; it is also a site where people can be held for years, but from whence people can be suddenly and forcibly removed.

\footnotetext{
${ }^{1}$ Immigration detention centres incarcerate two main groups of 'illegal' immigrants. The first are tourists and migrants who have stayed in Australia after their visa has expired and who are detained prior to deportation. The second group, and the focus of this paper, are asylum seekers who have entered Australia without a valid entry visa.
} 
This paper focuses on a period between January 2000 and December 2003. It is concerned with how male detainees protested their ongoing incarceration and is based on a series of in-depth interviews with men $^{2}$. I suggest that there is a gender dimension to both the rationale for detention and the forms of struggle against incarceration.

Masculinity is linked with dominance, threat and violence (Connell 2005) and the male asylum seeker is the embodied target of government action. Against the male body the government exaggerates and inflates an aggressive stance. The state regards the male border-crosser as a threat to sovereign power and the torsions of the detention regime are reactionary stances against this perceived menace.

A systematic scepticism governs and regulates the body of the detained and renders the immigration detention site inherently volatile. Thousands of protests by men and women - ranging from silent, individual acts of defiance to large-scale collective demonstrations - have disturbed the bureaucratic operation of detention. Frequently men protest by punishing their own bodies; through the denial of food and water, the slicing of skin and the suturing of lips. This self-inflicted punishment upon the male body deflects possible physical punishment meted out by the agents of the detention system; but detainees also attack the material space of detention and the architectonics of their incarceration. Asylum seekers have set fire to buildings and cut razor wire cut as they sought at least temporary escape from their confinement. Women have been involved in these methods of mass action, but the instigators and actors have typically been adolescent and adult males.

The paper points to three prevailing tendencies of collective protests. First, these demonstrations sought to effect change, particularly regarding the process of decisionmaking on refugee status claims. Second, protest action was overwhelmingly by male detainees who had been held for more than three months. Third, the methods and

\footnotetext{
${ }^{2}$ Men are the focus of this paper, but this is not intended to suggest that women were/are not involved in strategies of resistance. The focus is a reflection of the numerical dominance of men within the detention setting. Research for this paper included 20 formal face-to-face interviews with former detainees. Interviews were conducted outside of the detention centre space after I obtained ethics clearance from the University of Technology, Sydney. Ethical considerations, coupled with the cross-cultural and linguistic dimensions, shaped the focus of the research. The interviews explored individual experiences of immigration detention, rather than a highly detailed exploration of personal histories. After first contacting the interviewee by telephone to discuss the research, I would interview refugees in their home or in the home of a friend. The interviews took the form of open-ended and lengthy conversations.
} 
strategies commonly employed in the demonstrations repositioned the male detainee as an active masculine subject.

\section{Seeking asylum - a state of exception}

Australia's practice of detaining unauthorised asylum seekers is notoriously amongst the most rigid and total in the world. Immigration detention centres operate by distrust; and until their status as refugee (the 'man of rights') or illegal (the subject of another state) is confirmed by the destination state, the detained border crosser inhabits a space governed by the indistinction between law and lawlessness ${ }^{3}$. The asylum-seeking refugee is the corporeal symbol of the indivisible nature of human rights (derived as these rights are from the simple status of being human); yet in detention these so-called indivisible rights are fragmented, and most are actually suspended. Australia's detention system operates on the assumption that the identity, and thus the subject status of an undocumented asylum seeker, is still to be verified.

Whilst in immigration detention all detained asylum seekers are held under suspicion. The veracity of a person's name, history, experience and even emotions is suspect. Everything they knew and understood about their self is now questioned. The camps have no outside, only a tenuous past somewhere else and a hazy terrain that can barely be described as a future. Whilst interned, asylum seekers are insecure: they cannot assess if they will be verified, or dismissed and forced to depart.

Individuals who seek refuge thus enter a legal and psychic limbo, disconnected from the 'normal' world of individual respect and recognition - until they are specifically reattached to normality by recognition of their refugee status, or rejected, expelled back into a world without refuge. This innovative strategy, which separates human rights from asylum rights, is a means to manage the government's broad political goals ${ }^{4}$.

The moment that agreement is reached between the state and the asylum seeker - once their refugee status is confirmed - these polarities are removed. Only the state can

\footnotetext{
${ }^{3}$ The literature describing conditions within detention is relatively detailed. It includes; (HREOC 2004) and (Palmer 2005).

${ }^{4}$ Immigration is a necessary component of Australian government policy. A tightly managed immigration program that reaps identifiable economic benefits for Australian society is highly regarded by government and its officials. 'Illegal' immigration undercuts this controlled system.
} 
confer and recognise the subject, and the officially recognised refugee by legal definition has been reconfirmed as a subject of a state.

Agamben (1998, 2005) calls the space where an individual is placed and suspended from the usual rules of civil law a "state of exception”. For Agamben (1998) the refugee as non-citizen always calls into question the citizen-state relation, and always represents an exacting problem for the state. The stateless subject breaks up the naturalised identity between man and citizen, and between nativity and nationality - and thus throws into crisis the original political fiction of sovereignty. Ambergen proposes that the asylum seeker occupies a contradictory space in which law is used to postpone law, and in which the juridical subject of modern capitalist democracy is suspended outside the realm of subjectivity.

Agamben's overarching framework of modernity can be selectively applied to explore the multiple micro-acts of constraint that operate within the particular site of immigration detention. However, his account does not engage with questions of struggle. There is a history of protest within Australian detention centres that requires critical examination; and as Foucault's work reminds us, history does not happen as one dominant group wills it, but rather as a result of the interaction of human wills.

In Society Must be Defended (2003), Foucault considers how modern governance is tied to the management of the human body. The living body has become the site for "rights" and simultaneously for a system of punishment linked to the withdrawal or exclusion from rights. The main point of power's application is its control over life. The emergence of rights is embedded within the rise of "bio-politics". Foucault asserts that modern governance is not concerned with freedom but with management of populations. Put crudely, the lived body is the major issue for the application of modern power.

In his histories of the secretive sites of the prison and the mental asylum, Foucault draws attention to the practice of modernity in both respecting and violating liberty. Foucault's work suggests that the mechanisms of disciplinary power hide behind the principles of rights. These mechanisms manage and discipline the subject and serve to secure political rule through the agency of bureaucratic expertise. Foucault also suggests, however, that the power that excludes can also empower politically - simply because 
the exclusion is already a form of address and provides implicit recognition. For Foucault all political moments are contingent.

Foucault's interpretations of power and the body are additional points of theoretical anchorage. The body, he contends, even when imprisoned, exercises power to evade the apparatus of subjugation. Power is not possessed but rather is exercised (1977). There are many localised circuits, tactics, mechanisms and effects through which power circulates.

Power, Foucault suggests, marks the body - inscribing each and every human with the attributes of subjectivity. The body is moulded and it constructs resistances through modes of social supervision and discipline as well as self-reflection. In his reading of power there is always a field of alternate action. For Foucault, history is replete with the revolts of disqualified knowledges and with their insistent emergence in political struggles.

Although recognising that there are vast differences in the ability to exercise power between the dominating and the dominated subjects within the exceptional site of immigration detention, there still remains a contested relation between the dominating and the subjugated. The multiple agents of the detention regime exercise overt biopolitical power that shapes the actions of detained asylum seekers. The incarcerated defy this governing power through and with their bodies.

The conditions of exception are not hermetically sealed. The threshold position of asylum seekers - as border-crossers and seekers of rights - marks them at that moment as being without rights (except the right to biological life); yet they still hold a claim for future rights. The detainee as seeker of rights may be hidden but not completely eradicated. This dialectic tension feeds the conflicts found within this space.

\section{Incarcerating the male body}

The detention of undocumented asylum seekers has been a fixture in Australia since 1989, when 23 male asylum seekers landed at Penders Bay in Western Australia. Three years later a series of amendments to Australia's Migration Act (1958) provided a secure 
statutory basis for detention to last until the asylum seekers had been either granted a refugee visa or deported from Australia.

Immigration detention has developed in response to unauthorised male asylum seekers. Men and adolescent boys comprise the majority (habitually around 80\%) of all unauthorised asylum seekers attempting to enter Australia. The gender imbalance can be explained because young men, rather than women, are typically pursued by militias in their country of origin. These men invariably have certain positions of responsibility to their family and community (interviews with C1; A1; A6; A9) ${ }^{5}$ and thus they or their families have found the resources to enable them to flee. Male detainees commonly believe the future of others in their family is dependent on their quest for asylum (Browning 2005).

Until the introduction of the Temporary Protection Visa (TPV) in 1999, 75-80\% of detainees were men aged between 18 and 40 years (Crock \& Saul 2002: 77). The TPV prevents refugees sponsoring their spouses and children via the family reunion scheme. Consequently the people-smuggling route from Indonesia to Australia became the only possible avenue for a TPV holder to be reunited with his/her family. From 1999 there was a sharp rise in the numbers of women and young children journeying from Indonesia. Despite this increase, men and adolescent boys continued to outnumber female asylum seekers in detention.

Some literature has focused on the vulnerability of women and children in detention. Priest and Cox (2005) raise questions about the particular risk women may face within immigration detention. HREOC (2004) conducted its national inquiry into children in detention and reported numerous breaches of human rights against children. Gender has also been emphasised in advocacy to release detainees, with refugee groups highlighting the barbarity of locking up women and children. The activist group ChilOut placed children at the forefront of its campaign against detention ${ }^{6}$. The question of men, masculinity and detention centres has received little attention. Yet the incarceration of

\footnotetext{
${ }^{5}$ Interviewees are only "identified" by a number and letter. This was necessary due to the continuing vulnerability of some interviewees who hold temporary visas. The letter "A" refers to refugee participants. The letter " $\mathrm{B}$ " denotes a visitor to detention centres and the letter " $\mathrm{C}$ " denotes interviewees who were employed at onshore detention centres.

${ }^{6}$ The focus on the vulnerability of women and children has the potential to strengthen the legitimacy of detaining men.
} 
predominantly male bodies is a key not only to the operation of detention but also to the forms of protest that have occurred.

For male asylum seekers there is a near complete loss of control over the workings of their life that unsettles the cultural assumptions linking maleness with dominance. Detention deliberately restricts many of the activities ascribed to adult masculinity exacting limits over any work, study and physical movement. The enforced passivity and helplessness is antithetical to quintessential male roles. Former detainees ${ }^{7}$ indicate that shame, anger, fear and distrust are heightened components of their post-detention identity. Women are also exposed, but a traditional feminine role as primary nurturer continues chiefly intact.

Foucault did not offer any gender analysis, and any attempt to define what is meant by the term 'masculinity' is fraught with complexities. Socially and historically constructed, masculinity is contingent and fluid. Indeed, even within the individual male body, masculine identities are fractured and shifting, because multiple discourses intersect in any individual life. Adult masculinities are thus produced through a complex process of development involving negotiation in multiple social relationships and in specific historical circumstances. Connell points out that:

to the extent the term can be briefly defined at all, it is simultaneously a place in gender relations, the practices through which men and women engage that place in gender, and the effects of these practices in bodily experience, personality and culture (2005: 71).

Different masculinities exist in definite relation with each other, but often in relations of hierarchy and exclusion ${ }^{8}$. The biological male body is an inescapable part of this construction; but the material body does not confer masculinity but rather receives masculinity (or some fragment thereof) as its social definition (Connell 1987: 83). Men's bodies do not fix patterns of masculinity but they are still very important in the expression of masculinity - which constantly involves physical experiences, corporeal pleasures and the vulnerabilities of bodies. Although masculinities are fluid, there is a

\footnotetext{
${ }^{7}$ Including A; A4; A10; A9; A15; A16

${ }^{8}$ Poynting et al argue that questions of ethnicity should not be merely added on to debates on masculinities. (1998). Refugee male bodies are always imbued with particular understandings of race and ethnicity. However, it is beyond the scope of this paper to explore questions of ethnicity, masculinity and detention.
} 
social definition across cultures of men as dominant. Connell (1987) refers to a "hegemonic" masculinity of control and authority that is naturalised and legitimated.

Masculinity is quintessentially connected with violence, aggression and war (Connell 2005). This is in contradistinction with femininity which is linked to passivity and nurturing (Gatens 1991). These hegemonic associations legitimate the detention of the male body and, as the binary suggests, problematise the non-criminal detention of women and children ${ }^{9}$.

The detention space is menacing to all detained, but the physical violence in the centres most commonly involves male bodies. Fights and assaults between male detainees, and between male detainees and male guards, were commonplace. One Afghan refugee who was 16 when he was first detained at Woomera described how detainees were goaded into fights by some detention officers:

many detainees fight with officers, like there was an officer who would come to our donga and he would smash things and break things and they would use coarse language. And there was even a time when an officer had thrown the Koran, the Holy book into the rubbish bin and the people protested about that. There was another rude officer who ACM would especially use for the people, he would come and break the cupboards, throw the blankets away in the dirt. You know, breaking things and smashing things (A1).

It is a space of exaggerated masculinity - a hypermasculine space (Toch 1998). In a zone of hypermasculinity, violence is entrenched and the willingness to fight and the capacity for combat are measures of male self-worth. In his exploration of masculinity and prison violence, Toch argues that when men are together, tough and heroic figures are emulated (Toch 1998). Fighting is tied to bravery, fearlessness and heroism and is linked back to masculinity; to step back from fighting and to display fear is to show

\footnotetext{
${ }^{9}$ In a 2005 interview psychiatrist Dr Louise Newman identified detained fathers as being at particular risk:
}

There are very specific issues for men who are also fathers who are charged with, and experience themselves as failing in their duty to protect their wives and particularly their children, who witness the deterioration of their own family and who suffer a tremendous amount of guilt as a result of that. I think for those fathers they feel that they have totally not only let themselves down, but destroyed their children's lives (Browning 2005).

The vulnerability of fathers can be linked back to Connell's $(1987,2005)$ assessment that the nature of hegemonic masculinity is highly contradictory. Hegemonic masculinity on the one hand requires men to value dominance; but on the other, it is fulfilled in fatherhood, which requires a caring and protecting ability. In detention, men's incapacity to assume their traditional protective role for their families is a part of an emasculation process. Fathers can no longer imagine themselves being able to defend and protect their children and wives. 
feminised emotion (ibid: 173). Likewise, Van Deburg makes connections between forms of masculinity - "macho resistance" and various protest movements (Van Deburg 1997).

Allegations of physical violence are numerous and several have been documented in reports including the Palmer Report (2005). A former Australasian Correctional Management (ACM) Officer told this story about the deportation of an Algerian man from the Villawood detention centre.

We get this guy out of bed early in the morning. We pull the sheet off him. He's in his pyjamas or those long pants that those people wear. He clings on to the bedstead; this is a steel bedstead. My job is to unwind his fingers, struggling, shouting he won't go. There are nurses. First time I'd seen a "chemical restraint" used.

They must have broken about three needles on him. I'm thinking there must be a better way. This bloke's not an animal. Sometimes there's a smell. They've urinated or something. We put him in the fish bowl. That's like a cage. There were about six big blokes like me. Another tries to get these injections into him. But it's not working.

He scratches and there's blood. He's shouting he won't go back... When we get him into the aircraft we handcuff him to the seat. But he pulls the whole seat out of the floor. That was it. We got him off the plane and took him back. Next week we did it again. This time he went quietly. "Just give me the tablet", he said. "Don't inject me with that". I don't know what happened to him. I think he went to jail at the other end (Milne 2004).

During riots, fires and rooftop protests, the Centre Emergency Response Teams (CERTs) have used batons, tear gas, pepper spray, water cannons and electric prods to restrain male detainees (A6; A7; A10; B2). In another case, letters were sent in 2003 to Amnesty International and ACM detailing assaults against one Iranian asylum seeker while he was being transferred from one detention centre to another. The assaults included beatings to the man's legs with a baton, the application of leg cuffs and being bound and forcibly restrained in an aeroplane seat (B3).

\section{Protesting detention}

Many detainees respond to physical violence and the generalised uncertainties of their everyday existence through protest; and in the years 2000 to 2003, the overcrowding in detention centres heightened the capacity to collectively resist the mechanisms of 
constraint $^{10}$. The hunger strike became a dominant mode of protest for men and adolescent boys. It is one of the few strategies available to detainees - by denying themselves food and water they can protest their incarceration but limit the possibility of forced deportation.

A hunger strike in the remote Curtin detention centre in the Kimberley region of Western Australia in February 2000 marked an escalation of organised campaigns of resistance by male asylum seekers. Curtin reopened in mid-1999 to take hundreds of Middle Eastern and Asian asylum seekers. This outdated military air base had been designed to imprison a few hundred - but by January 2000 over 1100 asylum seekers were detained there. In the scorching summer heat about three hundred Iraqi detainees began a hunger strike. Of these, between twelve and twenty men sewed their lips together using needles and thread (Mares 2001: 10). These men could barely speak, for their lips could not open more than half a centimetre.

During the worst heat of the day, protesters would lie on old mattresses in the shipping containers that were used as bedrooms - the walls were hot enough to burn skin (C1). At other times the hunger strikers congregated outside their rooms and, at intervals, would chant: “Where is human rights? Where is freedom?” Scores of detainees took no food and little water for several days.

The Iraqi asylum seekers were protesting against perceived delays in processing their refugee claims, in comparison to the applications of Afghans. This highly organised protest sought a more systematic and responsive processing system. The men also wanted access to lawyers and to means of communication - at that point, detainees at the remote Curtin centre had been held incommunicado, with no access to telephones or to sending or receiving mail.

The sharp rise in detainee numbers made a series of mass protests at immigration detention centres around the country possible. In June 2000 nearly half of those detained at Woomera cut through the razor wire and walked the three kilometres into the Woomera township. This was soon followed by a hunger strike and breakout at the

\footnotetext{
${ }^{10}$ In January 1993, 560 people were detained; there were 1,410 in January 1996 and 3,574 in 1999. The numbers leapt to over 8,000 during 2000 and just below 8,000 in 2001(Crock \& Saul 2002: 80). Detainee numbers gradually declined after the 2001 Border Protection Legislation began to take effect.
} 
Villawood detention centre and then by hunger strikes and riots at Woomera. This was a pattern of protest that continued for the next four years.

Protesters had very specific aims (A1; A2; A4; A6; A7). One Hazara refugee said he joined a hunger strike after DIMA stopped processing Afghan applications in the wake of the 2001 invasion of Afghanistan by the United States. The Afghan hunger strikers called on DIMA to begin reprocessing their claims.

Yes. I was ten days, we are all men [in] camp on hunger strike. Because stopped processing. What's the problem? [We] had three demands for government. If you say I'm a terrorist, put me in jail directly [or], decide, if you want to give me freedom, [or] if you don't want me to stay... send me to another country or send me back to Afghanistan. So we have three demands. Give me my freedom as it is my right. We are on hunger strike (A6).

This man was convinced that this hunger strike resulted in his subsequent release from Woomera on a TPV. He said: "Delegates from government came and talked and started again interviews and then they decide and gave me a visa”.

The imposition on the self of pain through hunger and thirst is re-masculinising, for it tests the capacity of the man to resist the blandishments of acquiescence ${ }^{11}$. The selfinscribed infliction of pain upon the body both externalised an internal anguish and called attention to the protesters' objective: release from detention. These selfmutilating protests made reflexive connections between the violence by the detained upon their own body and the hypermasculine brutality of the detention system. The hunger strikes and lip sewing reflected back onto the body of the nation the signs of ferocity that are deployed within detention.

There was also spontaneous and planned violence against the detention setting. This included riots, arson, escapes and physical violence targeting guards. With few exceptions these actions were by male detainees, whose self-harming acts lashed out at their imprisonment in the face of inevitable repercussions. On June $5^{\text {th }} 2001$ riot-gearclad officers at Woomera attempted to stop a group of mainly Afghan asylum seekers from smashing windows, computers and musical instruments. The denial of visas for two of the detainees after other Afghans had received visas provoked this destruction.

\footnotetext{
${ }^{11}$ These hunger strikes were frequently broken by the forceful feeding of the hunger striker - marking the control of the state over biological life.
} 
The next day detainees threatened to riot again. Water cannons were moved into place and the guards donned their riot gear. The material surroundings, even the children's playroom, were smashed by rioters over the course of several days. The razor wire was cut and some men fled into the desert.

One man told me that in the aftermath of fires being lit at Woomera in 2002, ACM guards and managers were asking who had lit the fires. His response was to tell them to inquire not into the arsonist's identity but into his motive: “your question is wrong. You should ask: Why burn? Why burn? Why people suicide? Why hanging? Why jumping fence? Why drinking shampoo? This is the question. You ask: Who burn? This is not the question" (A6).

Another man said he helped organise a riot and breakout from Port Hedland after hearing of protests at Woomera in June 2000. He and several other detainees planned a breakout to protest against overcrowding, their inability to access lawyers and the overall conditions at the Port Hedland Immigration Reception and Processing Centre (IRPC). For this refugee the protest was also an attempt to delay what he believed to be his forthcoming deportation to Iran (A10). In the aftermath he was sent to Roebourne jail for three months. He recalled Roebourne as a relief from immigration detention. Another Iranian asylum seeker detained at Port Hedland said he assumed hypermasculine modes of being - to be rude and aggressive - to try to get results. This man in his twenties spent a total of five months in isolation during his four years of detention, and was beaten by guards on a number of occasions (A17).

In December 2003 Port Hedland was the site of another violent protest. The riot was sparked when a group of teenaged schoolgirls were denied entry to visit asylum seekers. Detainees were apparently told that the girls were denied entry for fear that they would be sexually assaulted by the detainees. Men climbed onto the roof and hurled rocks at ACM guards. Later an ACM officer reported the riot thus:

The mob became nasty and was becoming more aggressive... The detainees were armed with iron bars/sticks and missiles. They moved in to engage. We used our gas...Like the rest of the squad I used the gas in self-defence only I am aware of hitting three detainees with my streamer. The courage and discipline of the squad made me very proud... I do not know how long we were under fire from what appeared to be large pieces of concrete, rocks, sticks and iron bars. Out of nowhere something hit me on the left side and neck. I felt my legs buckle. I was stunned. I turned to my right and caught 
sight of the detainee running at our rear. At this instant I was struck again on the front right of the head. I was stunned felt dizzy and I believe lost consciousness (ACM Internal Incident Report 2003).

When the rioters were brought down from the roof, many were placed in isolation. There were claims of male asylum seekers being handcuffed, stripped and beaten. The group then responded with a hunger strike.

In 2001 medical doctor and detained asylum seeker Doctor Aamer Sultan and clinical psychologist Kevin O’Sullivan co-wrote a paper for the Medical Journal of Australia linking the systems of protest with temporality, suggesting that routines of resistance became more common in the wake of the first decision by DIMA to reject a claim for asylum. The authors suggest that the "sense of injustice overwhelms many detainees" (2001: 594) who then begin to protest their detention.

Sultan and O'Sullivan proposed four common stages in the psychological reactions of detainees to their incarceration over time. The first is a non-symptomatic stage in the early months of detention; then a second stage which they termed the "primary depressive stage”.

This second stage follows the first negative decision by DIMA. Sultan and O'Sullivan document that it is at this juncture - the point of first rejection and corresponding fear of deportation - that asylum seekers' determined to take “non-compliant” action against their detention.

The nature of the revolt varies: some become protesters (engaging in hunger strikes and other non-violent demonstrations); others become advocates (attempting to raise public awareness about the realities of detention); and some become aggressors (engaging in confrontations, riots, detainee-guard conflict and other inter-detainee violence) (594).

The protesting body is both the space for expressing mental anguish and the vehicle for challenging on-going detention. Collective protests are one way that men challenge the dehumanising processes of internment. The forms of male protest are struggles against acquiescence and resist the enforced passivity of imprisonment.

\section{Risking emasculation}

Refugees speak of detention as a zone enveloped by a particular state of madness - a space marked by asymmetrical power relations of calculated and involuntary torsions 
and contradictions. Male detainees walk a fine line between the threat of retribution and the fracturing of self though non-action. If they become too passive, they risk losing their sense of self altogether. But the fear of catastrophic reprisals dissuaded some men from any involvement with overt protests, particularly in the first few months of detention when most are fearful and anxious.

Woomera is like a jail, all fence, no trees, some persons sick. After three weeks no news for my visa I got headache and got sick in stomach because I was confused as to why I didn’t get my visa. I saw some people, one years, two years no visa, in jail, in Woomera jail (A7).

A refugee detained at Villawood for more than two years told me that dissent was too dangerous: he believed that if he protested he would be punished and possibly repatriated. To wait stoically and stay "out of trouble” were understood as his only options:

I can't do nothing. I just wait and wait. Better to keep quiet if you want to be released. Never ever go on hunger strike and you have to be good. I know one guy he has been waiting three, maybe four months for an answer and he rings RRT (Refugee Review Tribunal) and says "Can you tell me?" They say OK and that night they tell him he has been rejected. We don't want to ask them. Don't write to them and say why do you delay - they will reject us (A4).

He continued:

We don't know what's going to happen tomorrow, if we are going to be released or deported. I know an African boy, he has been there four years four years! He eats, sleeps, he has no choice. If he wants to escape he can escape. He doesn't want to. If you escape, you can't walk, if you see the police it's the same feeling as if I was in my own country, no point to leave here (A4).

In the period covered by this paper, many men sought non-aggressive methods to control elements of their environment and deliberately broke rules. At Curtin a distillery was created and men would drink the alcohol throughout the night. One man held at Baxter IRPC created a vegetable garden, despite regulations stipulating the area remain as a lawn. Even after receiving letters from the Department of Immigration seeking payment for damage to Commonwealth property, the man (and his wife) continued to work in the garden.

when one man dug a five metre squared garden patch from some of the grass strip using a plastic spoon... he also got a letter from the Department advising him that he had done damage to Commonwealth property to $\$ 40,000$ worth of lawn. He took no notice. (C1). 
However, any act of "non-compliance”, and in particular that of assertive protest, risked the body of the detained. Physical assault and segregation were common forms of punishment, but so too was the threat of repatriation (Steel et al 2004: 528; interviews with A1-A7 and A12-A17). Many were held in isolation units for indefinite periods. Even the threat of disturbances was sometimes enough for the authorities to segregate individuals (A4; A6; A7).

Some men suggested during interviews that they felt compelled to respond through protests that sought their release, or else they risked indefinite incarceration and madness. Toch argues that in a space of hypermasculine violence, to not respond physically to aggression is to risk emasculation (1998: 170-72). Femininity here is set in an oppositional relation to masculinity: when incarcerated men respond without violence, they are linked to the feminine, to emasculation and the loss of the male self.

For Agamben the man reduced to bare life is found in the space of exception and under "these conditions the human can be transformed into a non-human" (Agamben 1999: 52). It is a life which has reached an absolute limit: to be pushed further would be to cross into death. Agamben's "state of exception” draws us to the sanctioned and deadly violence perpetrated by the state, where legal process is undermined and superseded by a complex opaque system of bureaucratic management. The longer the incarceration, the greater the threat of an existence reduced to bare life.

Some detainees exist on that threshold between life and death - they are still living, but often not speaking or acting in a way that is fully human. Their state of mind is a response both to the horrors they have fled and to the violence of detention. Typically former detainees would describe some other detainees as mad:

I was there for eight months and when I saw a separate cage in which the most Irani or Iraqis were detained, they were like hungry lions. I would say most of the people were detained for two years at that time. So I would think that it would be very possible that I would be like one of them and they would take me to one of those cages. And those people were not treated as humans (A2).

In their pivotal study Sultan and O’Sullivan refer to a "secondary depressive stage” that follows the second rejection - the detainee's application to the Refugee Review Tribunal. The detainee now contemplates a limitless detention or deportation. The asylum seeker is more severely depressed and continues to seek ways to defy the 
detention regime. The asylum seeker's resistance is "less aggressive and largely associated with passive, non-compliant resistance and attempts to escape”.

Finally, Sultan and O’Sullivan identify a "tertiary depressive stage" where the detainee's “mental state is dominated by hopelessness, passive acceptance and overwhelming fear of being targeted or punished by the managing authorities” (Sultan et al 2001: 594-595).

For many men collective protests have been a critical means to respond and to disrupt the systematic incoherence of the detention system. This forceful dissent was a struggle for a coherence of self: the preservation of a specific and gendered identity.

\section{Conclusion}

Within the enclosed spaces of immigration detention the multiple and micro-acts of constraint that extrude the conditions of exception are continually challenged. The explicit protests - the hunger strikes, breakouts and riots - have been a response to the constraining system of incarceration, and have sought particular resolution. In guarding against psychological disintegration of the self in this dehumanising space, male detainees have developed avenues for re-establishing a sense of active purpose and assertion of masculine identities.

Male detainees dominate the detention space and various forms of male protest resist and repulse the conditions of exception. These violent protests and retaliations bring into sharp relief the impasse of the detention regime. Agamben's critique of modernity implies that every effort is pointless - but even within a detention camp, the conditions of exception are not total and there is an intense and bitter struggle against absolute acquiescence.

The differing forms of masculine protest challenge the enfeebling tendencies of detention and question the right of the state to violently constrain the non-criminal body. Particular forms of male protest and resistance - including hunger strikes, riots and escapes - struggle against a painful disintegration of identity and a symbolic emasculation. 


\section{Bibliography}

Agamben, G (1998) Homo Sacer: Sovereign Power and Bare Life, trans. D.H. Roazen, Stanford, Stanford University Press.

Agamben, G (1999) Remnants of Auschwitz: The Witness and the Archive, trans. D.H. Roazen, New York, Zone Books.

Agamben, G (2005) State of Exception, trans. K. Attell, Chicago, University of Chicago Press.

Browning, J (2005) “If this is a Man? Men and Mandatory Detention”, All in the Mind radio program, 8 October, Sydney, ABC Radio National.

Connell, R.W (1987) Gender and Power: Society, the Person and Sexual Politics, Sydney, Allen \& Unwin.

Connell, R. W (2005), Masculinities, 2nd edn, Crows Nest, Allen and Unwin.

Cox, E \& Priest, T (2005) Women in Detention: More questions than answers, Sydney, University of Technology.

Crock, M ed. (1993) Protection or Punishment? The Detention of Asylum Seekers in Australia, Leichhardt, Federation Press.

Crock, M \& Saul, B (2002) Future Seekers: Refugees and the Law in Australia, Annandale Federation Press.

Department of Immigration and Multicultural Affairs (2003) Managing Migration, $2^{\text {nd }}$ edn, Canberra, DIMA.

Foucault, M (1977) Discipline and Punish: The Birth of the Prison, trans. A. Sheridan, Middlesex, New York Peregrine.

Foucault, M (1978) The History of Sexuality, An Introduction, Volume 1, trans. A. Sheridan, New York, Vintage.

Foucault, M (2003) Society Must Be Defended: Lectures at the Collège de France 19751976, M. Bertani \& A. Fontana, (eds) trans. D. Macey, London, Penguin.

Gatens, M (1991) Feminism and Philosophy: Perspectives on Difference and Equality, Cambridge, Polity Press.

HREOC (1998) Those who've come across the seas: Detention of unauthorised arrivals, Canberra, Human Rights and Equal Opportunity Commission.

HREOC (2001) Report on Visits to immigration Detention Facilities by the Human Rights Commissioners, Sydney, HREOC.

HREOC (2004) A last resort? National Inquiry into Children in Immigration Detention, Sydney, HREOC.

Mares, P (2001) Borderline: Australia's Treatment of Refugees and Asylum Seekers, , Sydney, University of New South Wales Press.

Milne, F (2004) Case Studies of Deportation from Australia, viewed 6 November 2005, $<$ http://www.aph.gov.au/senate/committee/legcon_ctte/migration/submissions/sub 174att_5.pdf>

Minister for Immigration, (2001) Media Release, Approval Rate for Boat Asylum Seekers falls, MPS, 112/2001, viewed 30 May 2003, 
<http://www.minister.immi.gov.au/media_releases/ruddock_media01/r01112.htm

$>$

Palmer, M (2005) Inquiry into the Circumstances of the Immigration Detention of Cornelia Rau, viewed 12 November 2005, <http://www.minister.immi.gov.au/media_releases/media05/palmer-report.pdf>

Poynting, S, Noble, G \& Tabar, P (1998) “'If anybody calls me a wog, they wouldn't be speaking to me alone': Protest Masculinity and Lebanese Youth in Western Sydney”, Journal of Interdisciplinary Gender Studies, 3(2): 76-94.

Silove, D \& Steel, Z (1998,) The Mental Health and Well-Being of On-Shore Asylum Seekers in Australia, Sydney, Psychiatry Research \& Teaching Unit, University of New South Wales.

Silove, D (1999) “The Psychosocial Effects of Torture, Mass Human Rights Violations and Refugee Trauma: Towards an Integrated Conceptual Framework”, Journal of Nervous and Mental Disease, 187(4): 200-207.

Steel, Z, Momartin, S, Bateman, C, Hafshejani, A, Silove, D, Everson, N, Roy, K, Dudley, M, Newman, L, Blick, B \& Mares, S (2004) "Psychiatric status of asylum seeker families held for a protracted period in a remote detention centre in Australia”, Australian and New Zealand Journal of Public Health, 28(6): 527-36.

Sultan, A \& O’Sullivan, K (2001) "Psychological disturbances in asylum seekers held in long term detention: a participant-observer account”, Medical Journal of Australia, no.175: 593-96.

Toch, H (1998) "Hypermasculinity and Prison Violence" in L Bowker (ed.) Masculinities and Violence, London, Sage.

Van Deburg, W (1997) Modern Black Nationalism: From Marcus Garvey to Louis Farrakhan, New York, NYU Press. 